\title{
TETANUS IN A SURGICALLY CASTRATED BEETAL BUCK: A CASE REPORT
}

\author{
Imaad Rashid, Junaid Ahmad, Awais-ur-Rehman Sial, Ghulam Muhammad and Muhammad Saqib \\ Department of Clinical Medicine and Surgery, Faculty of Veterinary Science, University of Agriculture, Faisalabad, Pakistan \\ *Corresponding address: profdrgm54@gmail.com
}

This is an open access article distributed under the Creative Commons Attribution License, which permits unrestricted use, distribution, and reproduction in any medium, provided the original work is properly cited.

\begin{tabular}{|c|c|}
\hline ARTICLE DETAILS & ABSTRACT \\
\hline Article History: & $\begin{array}{l}\text { Tetanus is a fetal disease of human and animals caused by spore forming, Gram-positive, anaerobic bacterium } \\
\text { Clostridium tetani. In present report, a } 16 \text {-month old, Beetal buck, weighing about } 40 \mathrm{~kg} \text { was presented to outdoor }\end{array}$ \\
\hline Received 9 July 2017 & clinics of Department of Clinical Medicine and Surgery, University of Agriculture, Faisalabad, Pakistan with \\
\hline Accepted 15 October 2017 & complaint of anorexia, abnormal gait and gradual loss of body condition. History, indicated that animal was \\
\hline Available online 6 November 2017 & $\begin{array}{l}\text { castrated } 12 \text { days before by a local quack using an ordinary shaving blade. Visual examination revealed that wound } \\
\text { had not properly healed on the day of examination. Physical examination revealed stiffness of fore and hind limb }\end{array}$ \\
\hline Keywords: & $\begin{array}{l}\text { muscles, prolapse of nictitating membrane and hyperesthesia. Owing to the presence of contaminated wound and } \\
\text { clinical signs, Beetal Buck was diagnosed as tetanus. Animal was treated with procaine penicillin @ } 44,000 \text { IU }\end{array}$ \\
\hline $\begin{array}{l}\begin{array}{l}\text { Tetnus, Beetal buck, } \\
\text { Clostridium } \\
\text { hyperesthesia }\end{array} \\
\end{array}$ & $\begin{array}{l}\text { IM } / \mathrm{Kg} \text {, diazepam @ } 0.1 \mathrm{mg} / \mathrm{kg} \text { IM. The treatment was prescribed for five days. Wound was debrided and washed } \\
\text { with hydrogen peroxide. On the 3rd day of this treatment, trismus was reduced and the gait of the animal was } \\
\text { improved. All in all, tetanus was present in goats and treatment afforded an improvement in health parameters. }\end{array}$ \\
\hline
\end{tabular}

\section{INTRODUCTION}

Unlike Tetanus is an infectious and potentially fatal neuromuscular disorder of animals and human. It caused bya spore forming, Grampositive, anaerobic bacterium Clostridium tetani. Spores are ubiquitous in the soil and resistant to destruction. Other reservoir of spore is gut of animals $[1,2]$. Causative organism of tetanus (C.tetani) produces two types of toxins viz. tetanolysin and tetanospasmin. Tetanolysin (necrotizing toxins) creates favorable conditions while tetanospasmin causes clinical signs. The incubation period in tetanus is variable. However,it depends upon the location of wound/injury and distance of wound from CNS [3,2]. Clinically disease is characterized by prolapse of third eye lid, hyperesthesia, stiff gaittrismus (lock jaw), generalized stiffness of the body including head and neck. Tail is also stiff and looks like 'pump handle'. In advanced stage, the affected animal is incapable to swallow due to the involvement of pharyngeal and laryngeal muscles. Other manifestations of the tetanus are drooling of saliva, bloat and aspiration pneumonia [1-3].

Disease occurs in a wide range of hosts including goats and sheep [4]. All age groups are susceptible to this infection-disposing factors of tetanus in small ruminants includes hearing, punctured wound, dehorning, disbudding, dystocia, tattooing, parturition, trimming of hoof and castration [5]. In lambs, the wounds resulting from castration and docking in contaminated yards may be followed by tetanus [6].

Tetanus occurs all over the world but reports in Pakistani goats are extremely scarce. As far as could be ascertained, only one case of tetanus was recorded from January 2003 to June 2007 veterinary dispensaries of Gilgit, Pakistan [7].

\section{CASE DESCRIPTIONS}

A 16-month old, Beetal buck, weighing about $40 \mathrm{~kg}$ was presented to outdoor clinics of Department of Clinical Medicine and Surgery, University of Agriculture, Faisalabad, Pakistan with complaint of anorexia, abnormal gait and gradual loss of body condition. About 12 days ago, this buck was castrated by a local quack using an ordinary shaving blade. Visual examination revealed that wound had not properly healed on the day of examination (Figure 1). Tail of the subject buck was stiff and erected ("pump handle tail"; Figure 2). Physical examination revealed stiffness of fore and hind limb muscles. Trismus (spasm of the jaw muscle), prolapse of nictitating membrane (Figure 3) and hyperesthesia were also noticed.
Moreover, salivation and flaring of nostril were also observed due to aspiration pneumonia. Rectal temperature $\left(103^{\circ} \mathrm{F}\right)$, pulse rate (71beats/mins) and respiration rate 39 breaths/min were in normal range. Owing to above mentioned clinical picture, tetanus was diagnosed in buck.

\section{TREATMENT}

Buck was treated with procaine penicillin @ 44,000 IU IM/Kg, diazepam @ $0.1 \mathrm{mg} / \mathrm{kg}$ IM. The treatment was prescribed for five days. Woundwas debrided and washed with hydrogen peroxide. On the 3rd day of this treatment, trismus was reduced and the gait of the animal was improved.

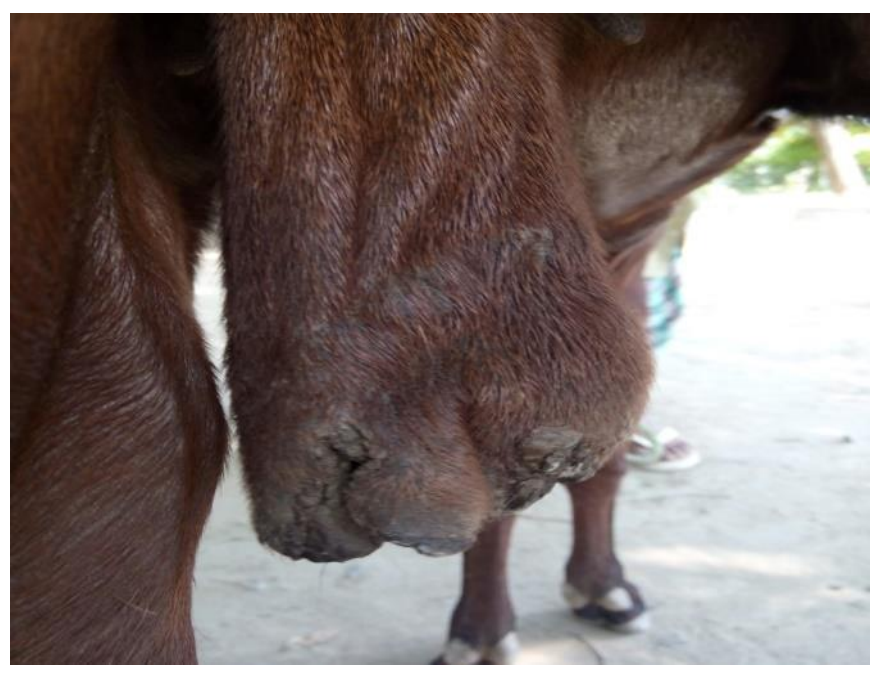

Figure 1: Wound on scrotum of a 16 months old Beetal buck after surgically removal of testes bya quack. Wound had not properly healed 


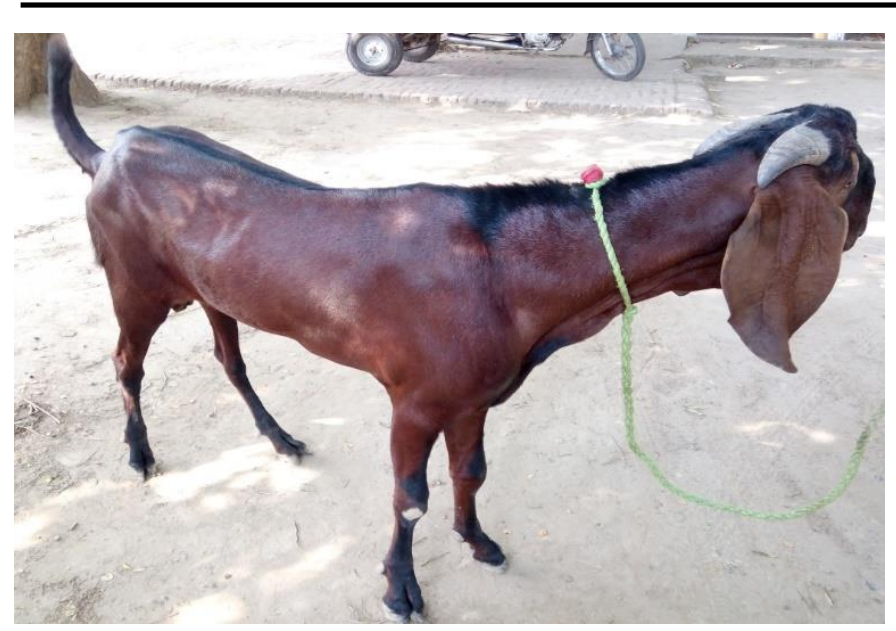

Figure 2: Abnormal standing posture of a 16 months old Beetal buck suffering from the tetanus. The tail of this buck was in erected position. Muscles of the fore limb and hind limb were stiff.

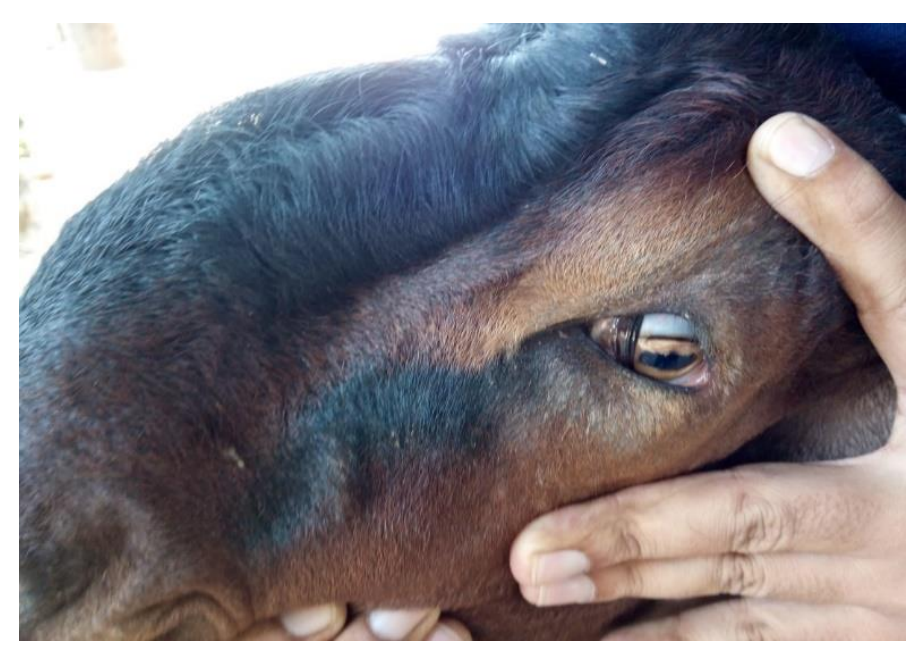

\section{DISCUSSION}

Tetanus is a bacterial disease caused by Clostridium tetani (Gram's positive bacteria). It causes toxemia by producing specific neurotoxins anaerobically in the tissue. During the unfavorable condition, bacterium changes into spores that are present in the soil all over the world. All mammals are susceptible to infection, among all mammals, horses and lambs are more sensitive to attain tetanus infection. Nonetheless, however, goats are also very susceptible to tetanus $[1,3]$.

Predisposing factors of tetanus infection including shearing, puncture wounds, castration and surgical interventions. In present case report, a 16-month-old Beetal buck was castrated surgically without maintaining aseptic conditions with ordinary blade. Wound become contaminated and animal developed stiffness of the body muscles, lock jaw and prolapse of third eyelid. Owing to the presence of contaminated wound and clinical signs Buck was diagnosed as tetanus.

\section{REFERENCES}

[1] Radostits, O.M., Gay, C.C., Hinchcliff, K.W., and Constable, P.D. 2007. Veterinary Medicine: A Textbook of the Diseases of Cattle, Sheep, Pigs, Goats and Horses. 10th Edi.Saunders-Elsevier, London, 822 - 824.

[2] Pugh, D.G., and Baird, A.N. 2012. Sheep and Goat Medicine. Elsevier, London, 398-399.

[3] Smith, M.C., and Sherman, D.M. 2009. Goat Medicine, Willey-Blackwell, 207-208.

[4] Guilfoile, P., and Babcock, H. 2008. Deadly Diseases and Epidemics: 2008. Tetanus, Chelsea House, 18.

[5] Connor, B., Leavitt, S., and Parker, K. 1993. Tetanus in feeder calves associated with elastic castration. Canadian Veterinary Journal, 34, 311 312 .

[6] Aitken, I. D. 2007. Diseases of Sheep. 2007. $4^{\text {th }}$ Ed. Blackwell Publishing, London, UK, 165-166.

[7] Naqvi, A.N., and Fatima, K. 2012. Incidence of livestock diseases in Nomal and Naltar Valleys Gilgit, Pakistan. Pakistan Journal of Agricultural Sciences, 25, 69-75

Figure 3: Prolapse of $3^{\text {rd }}$ eye lid of tetanus affected buck 